\title{
Why Tip? \\ An Empirical Test of Motivations for Tipping Car Guards
}

\author{
Stephen G. Saunders* \\ Department of Marketing, Monash University \\ PO Box 1071, Narre Warren, Victoria 3805, Australia \\ Tel: +61 399047028 \\ Email: stephen.saunders@buseco.monash.edu.au \\ Michael Lynn \\ School of Hotel Administration, Cornell University \\ 552 Statler Hall, Ithaca, NY 14853-6902, USA \\ Tel: +1 6072558271 \\ Email:wm13@cornell.edu
}

Journal of Economic Psychology

*Please address all correspondence to Stephen Saunders 


\begin{abstract}
From a mainstream economic perspective, tipping is often seen as a rather anomalous or irrational economic activity since consumers could legally and willingly avoid paying tips altogether. Nevertheless, this pervasive economic activity generates tens of billions of dollars in income a year, worldwide. In order to better understand this seemingly irrational behavior to tip, this study investigates other potential motives for tipping that draw from the behavioral economics and psychology literature. We test several of these motives in the context of tipping car guards in South Africa and find evidence supporting the ideas that tipping is motivated by desires to: reward good quality service, help service workers, and gain social approval.
\end{abstract}

JEL classification: Z13, A12, D80

PsycINFO classification: 2229, 3900, 3920

Keywords: tipping, car guard, service quality, gratuity, social norm 


\section{Introduction}

Consumers of various services around the world will often leave voluntary sums of money (called "tips" or "gratuities") to the workers who have served them. Among service workers commonly receiving tips are barbers, bartenders, cab drivers, casino croupiers, concierges, deliverymen, doormen, exotic dancers, golf caddies, hotel maids, maitre d's, masseuses, parking valets, pool attendants, porters, restaurant musicians, washroom attendants, waiters, shoe-shiners, and tour guides (see Star, 1988). For many of these service workers, tips represent a substantial portion, if not the majority, of their income (Payscale, 2009). Consequently, in the U.S. food industry alone, estimates place the total amount of income generated from tips at over $\$ 40$ billion a year (Azar, 2009), making tipping a pervasive and important economic activity.

Tipping is also a rather unique economic activity because it is a voluntary expense that consumers could avoid paying altogether (Lynn, 2006). From a mainstream economics perspective, consumers are motivated by rational self-interest (i.e. homo economicus) and so, as a general rule, would pay as little as possible for goods and services, in order to maximize satisfaction or utility (Frank, 2006; Lee, Amir and Ariely, 2009). Since tips are not legally required and are typically paid after a service has been rendered (and hence are not necessary to ensure good quality service at infrequently patronized service establishments), avoiding tipping could be viewed as rational economic behavior. Thus, tipping is an anomalous economic behavior in need of explanation. As Azar (2008) writes, "one of the most interesting and central questions about tipping is why people tip". This paper addresses that question by presenting and testing different theorized motives for tipping behavior.

\section{Theorized Motives for Tipping}

A perusal of the tipping literature reveals numerous theorized economic and psychological motives for why a consumer would engage in seemingly irrational consumer behavior (see Lynn, 2009). The most commonly discussed motives for tipping service workers are: (i) to gain good quality service in the future, (ii) to reward good 
quality service, (iii) to help service workers, (iv) to gain social approval or avoid social disapproval, and (v) to conform to internalized tipping norms (see Azar, 2005, 2007a, 2007b, forthcoming; Lynn 2006; Lynn and Grassman, 1990). The relevant literature on each of these motives is further discussed in the sections that follow.

\subsection{Gaining Good Quality Service in the Future}

The hypothesized motive for tipping most consistent with mainstream economic theory is that customers tip in order to gain good quality service in the future. There are two versions of this explanation. The first version assumes that both tippers and service workers are rational economic actors who derive satisfaction or utility only from economic goods and services. In this case, it is rational for frequent customers of an establishment to leave tips that are contingent on service quality, so that service workers become aware of the contingency and have an incentive to deliver good quality service. Thus, this version suggests that the tips of frequent customers will be more strongly and positively affected by service quality than are the tips of infrequent customers. Empirical tests of this hypothesis, however, have not been supportive (Azar, 2008; Conlin, Lynn and O'Donoghue, 2003; Lynn and McCall, 2000). Nevertheless, these tests have been conducted in the context of restaurant tipping, making it possible that relatively strong social norms, intimate server-customer contact, and/or other factors associated with restaurant dining make restaurant tipping less rationally motivated than tipping in other service contexts. For these reasons additional research is needed to test this interaction effect outside of the restaurant context.

The second ("weaker") version of this explanation assumes that tippers are rational in the mainstream economic sense, but that service workers are irrational in that they derive satisfaction or utility from repaying customers for past tipping generosity. In this case, it is rational for frequent customers to leave larger tips than infrequent customers (irrespective of service quality), because the frequent customers will derive more benefit from their reputation of being a good tipper. Thus, this version suggests that frequent customers will tip more than infrequent customers. Consistent with this hypothesis, researchers have found that frequent customers leave larger tips than 
infrequent customers at restaurants (Azar, 2008; Conlin, et. al., 2003; Lynn and McCall, 2000). ${ }^{1}$ Moreover, this effect remains significant even after controlling for customers' perceptions of food and service quality (Conlin, et. al., 2003; Lynn and Grassman, 1990). This means that frequent customers do not tip more than infrequent customers simply because they perceive the food and service quality to be better. However, Azar (forthcoming) warns that potential confounds (i.e. income) have not been controlled in these studies, and may explain the relationship between tip size and patronage frequency. As a consequence, further research that includes additional covariates is needed to test alternative explanations for this hypothesized relationship.

\subsection{Rewarding Good Quality Service}

The most common motive for tipping reported by consumers themselves is the desire to reward good quality service (Lynn, 2009). This explanation of the motive for tipping is consistent with psychological theory. In particular, research on the norm of reciprocity (Regan, 1971) and equity theory (Adams, 1965; Walster, Berscheid, and Walster, 1973), both suggest that customers derive satisfaction or utility by compensating service workers for the benefits they provide. Furthermore, numerous studies have found that restaurant customers tip more for better service, even when controlling for potential confounds and reverse causal effects (Lynn and McCall, 2000). These empirical findings therefore provide considerable support for this hypothesized motive. Nevertheless, the relationship between service quality and tip size is rather weak (a correlation coefficient of only .2) suggesting that consumers desire to reward service quality does not appear to be as strong a motive for tipping as self-reported by consumers themselves. Moreover, almost all previous research on tipping as a reward for service has been conducted in restaurant settings. More research is therefore needed to test this hypothesized motive in other service contexts.

\footnotetext{
${ }^{1}$ Researchers have also found that service workers do deliver better service to those customers thought to be better tippers (Barkan and Israeli, 2004), which supports the assumption about service workers' utility functions that underlies this version of the future service motive for tipping.
} 


\subsection{Helping Service Workers}

The second most common motive for tipping reported by consumers themselves is the desire to help service workers (Lynn, 2009). This motive is also frequently mentioned by behavioral economists as a potential explanation for tipping (Azar, 2004; Frank, 1988, 2006; Schotter, 1979). Consistent with this hypothesized motive, various tipping studies have shown that: (i) tips increase with patronage frequency (because familiarity increases empathy) and server friendliness (because friendliness increases empathy) (see Lynn, 2006), (ii) occupations are more likely to be tipped the lower the service workers' income and the greater the psychological closeness between the service worker and consumer (Azar, 2005), and (iii) people who say they tip to help others do tip more than others (Lynn, 2009). However, Lynn's and Azar's findings are also consistent with other motives for tipping such as the customers desire for the service workers personal approval, and therefore may not be entirely altruistic. Further doubt about customers' motive to help service workers (i.e. altruistic motives) is indicated in Lynn's (2008) study which established that "tenderhearted" customers are no more likely to tip than "non-tenderhearted" customers. Thus, there is a need for more research to test this hypothesized motive for tipping, especially in understudied service contexts outside of U.S. restaurants.

\subsection{Gaining Social Approval}

Although not as widely mentioned by consumers as other motives to tip (Lynn, 2009), the desire to acquire social approval (or status) and/or to avoid social disapproval (or embarrassment) are frequently cited by economists as potential motives for tipping (Azar, 2004; Bodvarsson and Gibson, 1997, 1999; Conlin, et. al., 2003). Empirical support for this hypothesized motive is mixed. On one hand, tipping is more prevalent in nations whose people and culture stress social status (Lynn, 1997; Lynn, Zinkhan and Harris, 1993). On the other hand, tipping is unrelated to individual differences in susceptibility to normative influence and restaurant tip percentages are negatively rather than positively related to individual differences in reported self-presentational motives for 
tipping (Lynn, 2009). Clearly, more research is needed to clarify the role of social approval (or status) motives in tipping behavior.

\subsection{Conforming to Internalized Tipping Norms}

A final motive that many economists have hypothesized may underlie tipping behavior includes satisfaction or utility derived from conformity with internalized tipping norms (Azar, 2004; Bodvarsson and Gibson, 1997, 1999; Conlin, et. al, 2003). Customers that internalize tipping norms should gain utility or a sense of pride when conforming to these norms and should lose utility or feel a sense of guilt from failing to conform to these norms. Although many consumers do report that they internalize tipping norms to gain satisfaction from "doing what is right", these customers neither tip more frequently nor tip larger amounts that customers that disavow such motives (Lynn, 2009). In another study, Lynn (2008) did find that liking/support for restaurant tipping was positively related to the tip percentages that customers typically left restaurant service workers. However, the relationship may have reflected an inhibitory effect of opposition to tipping rather than a positive motivating effect of internalized support for tipping. Thus, this hypothesized motive for tipping is also in need of additional testing.

\section{Study Context and Methodology}

The current study examines the tipping motives discussed in Section 2 in the context of car guard tipping in South Africa. Car guarding is the act of watching (or "guarding") a car at a public parking space in the driver's absence, so potentially acting as a deterrent to would-be car thieves (McEwen and Leiman, 2008). While the core service is to guard the car, the car guard often provides augmented services such as pointing the way to empty parking spaces, directing parking maneuvers, loading packages, and returning trolleys. In addition, McEwen and Leiman (2008:5) report that "a secondary function of car guards is to keep the more intimidating drunks and homeless from harassing motorists". Thus, an important element of the services that car guards render is being polite and presentable and keeping other disreputable people away. 
The car guarding industry emerged in the early 1990's due to high levels of unemployment coupled with very high rates of car-related crimes (Blaauw and Bothma, 2003). According to Bernstein (2003) the car guard industry in South Africa began as a very informal activity -considered to be just a variation of begging - but has progressively become more formalized in all major urban areas. Today most shopping centers, (together with many schools, hospitals and restaurants) provide easily recognizable shirts or jackets, name tags and equipment to car guards that work in the vicinity, even though the guards are not employed by the company or organization and are totally responsible for generating their own income through tips (Blaauw and Bothma, 2003). Car guards are typically low-skilled service workers who work long hours under harsh conditions, earning very low incomes through the tips they receive. No official statistics are available on the number of persons working in this informal sector occupation, but it is likely that the numbers run into the hundreds of thousands of people given that most public parking spaces in urban areas of South Africa typically have car guards.

It is important to note that the money given to car guards are genuine tips and not bribes or extortion payments ensuring that the car guards or their friends do not vandalize the cars of paying parkers. For one thing, the payments to car guards are given after service has been rendered rather than beforehand. While a car guard could keep records (like license plate numbers) of who does and does not tip in order to punish non-tippers the next time they park in the car guard's area, the number on non-tippers (around 30 percent of parkers) is too large and the size of most tips (typically R2.00 or US\$0.25) is too small to justify such effort. Furthermore, the non-tippers in our study sample reported no abuse from the car guard or damage to their cars. These facts suggest that payments to car guards are genuine tips and not bribes.

Data on car guard tipping was collected through an anonymous self-administrated structured questionnaire that relied on pre-existing validated measurement scales where possible. After pre-testing on a sample of respondents considered representative of the study population (based on the gender, age and racial group), a total of 29 fieldworkers were asked to conveniently select 20 respondents living in their local community (a total of sample size of 580). This sampling procedure produced a total of 575 respondents who completed the questionnaire. Only five blank questionnaires were returned. When 
cleaning the data it was found that 45 questionnaires were unusable as the respondents were either inconsistent in the responses or unable to recall the exact details of their interaction with the car guard. The final sample was therefore 530 responses, but because of missing values for some variables, sample sizes did vary slightly across the analyses reported. Respondents were asked to answer questions relating to their most recent service encounter with a car guard, and other relevant demographic and situational characteristics. The specific variables measured included the following:

\subsubsection{Tipping}

Consumers self-reported tipping behavior was measured through two different dependent variables: a binary tip variable (yes/no to tipping) and tip size variable (in local currency, the South African Rand). A natural log transformation of tip size was used in the analyses reported in Section 4 to deal with outliers and to ensure that the residuals from our regression analyses were more normally distributed.

\subsubsection{Service Quality.}

Perceived service quality was measured by adapting Bodvarsson et al.'s (2003) service quality scale. On a five-point scale ranging from "strongly disagree" to "strongly agree" respondents were asked to indicate the extent to which they agreed that the car guard was neat, friendly, attentive and prompt. This service quality measure, which was obtained by summating the individual items, had a Cronbach's coefficient alpha of .81.

\subsubsection{Helping Motives}

Customers helping motives was measured by adapting Webb, Green and Brashear's (2000) attitude to helping others scale. On a five-point scale ranging from "strongly disagree" to "strongly agree" respondents were asked to indicate the extent to which they agreed on four items regarding "helping or assisting other people in need" or "who are less fortunate". This measure, which was obtained by summating the individual 
items, had a Cronbach's coefficient alpha of .87.

\subsubsection{Attitude to Tipping}

Internalization of tipping norms was measured on a five-point scale ranging from "strongly disagree" to "strongly agree". Respondents were asked to indicate the extent to which they agreed on two items that assessed respondents' attitudes toward tipping (i.e. "Tips given to car guards goes to a good cause" and "Much of the tips given to car guards are just wasted"). This measure, which was obtained by summating the two items, had a significant correlation coefficient of .42 (after reverse scoring the second item).

\subsubsection{Attitude toward Car Guards.}

Attitudes toward car guards were measured on a five-point scale ranging from "strongly disagree" to "strongly agree". Respondents were asked to indicate the extent to which they agreed on two items that assessed respondents' attitudes toward car guards themselves (i.e., "My image of car guards is positive" and "Car guards perform a useful function for society"). This measure, which was obtained by summating the two items, had a significant correlation coefficient of .59.

\subsubsection{Social Norms.}

Social norms assessed the normative beliefs held by four influential social connections (i.e. family, friends, peers and leaders) of the respondent with respect to tipping of car guards. Respondents were asked to indicate the extent to which the four influential social connections believed that people should tip. These normative beliefs were measured on a five-point scale ranging from "definitely not tip car guards" to "definitely tip car guards". The final social norm measure, which was obtained by summing the normative beliefs of the four social connections, had a Cronbach's coefficient alpha of .78 . 


\subsubsection{Demographic Characteristics}

Demographic characteristics have been shown in previous studies to be significant predictors of tipping and so are included in the regression analysis (Lynn, 2004; Lynn et al., 2008). Demographic characteristics of the respondent included: age, sex, income status, and racial status. Respondents also reported on the perceived demographic characteristics of the car guard: car guard's racial status and national origin (South African, Foreign, Not sure). National origin was dummy coded into two variables with 142 "not sure" responses as the un-coded comparison.

\subsubsection{Situational Characteristics}

Situational characteristics have also been shown in previous studies to be significant predictors of tipping and so are included in the regression analysis (Lynn and Grassman, 1990; Lynn, Zinkhan and Harris, 1993; Bodvarsson and Gibson, 1997; Bodvarsson et al., 2003). Situational characteristics of the service encounter were assessed with questions about location, day of week, time of day, frequency of parking in that lot/area, weather, presence of others in the car and the possession of cash/change.

\section{Results and Discussion}

Descriptive statistics for the study variables are presented in Table 1. As can be seen, all the measures had sufficient variability for meaningful inclusion in multivariate analyses. Given that the decision to tip (or not) can be distinguished from the decision about how much to tip (i.e. tip size) and that these decisions have been shown to have different predictors in previous research (Schwer and Daneshvary, 2000), we used the information from our survey to create both dependent variables and analyzed them separately - using binomial logistic regression to analyze tip (or not) and OLS regression to analyze tip size. The analyses of tip size excluded those who did not leave a tip, so the results of those analyses only deal with how much is tipped by those who actually do tip. As previously mentioned, a natural $\log$ transform of tip size was analyzed to avoid 
problems with outliers and to make our error terms more normally distributed. Each dependent variable was analyzed with two regression models - the first using all the other study variables as simultaneous main-effect predictors and the second examining two interaction effects by adding the products of (i) social norm by others present and (ii) service quality by patronage frequency to the model. The results of these analyses are presented in Table 2. The key findings are as follows.

First, patronage frequency had no significant effects on either tip $(\beta=.12$, Wald $(1)=.48$, n.s. $)$ or tip size $(\beta=.07, \mathrm{t}(1,322)=1.58$, n.s. $)$. Nor did it interact with service quality to affect either tip $(\beta=-.33$, Wald $(1)=2.31$, n.s. $)$ or tip size $(\beta=-.07, \mathrm{t}(1,320)=$ -1.20, n.s.). These findings are inconsistent with both the strong and weak versions of the future service explanation for tipping and suggest that the desire for good service in the future does not underlie consumers' decisions about tipping car guards in South Africa. This is not to say that South Africans do not care about future service, but that tipping is not seen as a means to ensure good future service from car guards. Perhaps this is because car guards have many customers and minimal contact with each, so consumers consider it unlikely that they or their tipping behavior will be remembered - even by car guards at frequently used parking areas. Future researchers may want to keep this possibility in mind and test the future service explanation for tipping in contexts where service workers have greater contact with fewer numbers of customers.

Second, perceived service quality was significantly positively related to both tip $(\beta=.73$, Wald $(1)=11.50, \mathrm{p}<.002)$ and tip size $(\beta=.14, \mathrm{t}(1,322)=2.22, \mathrm{p}<.03)$, supporting the idea that consumers in South Africa tip car guards in order to reward them for the services they render. This finding is particularly interesting because as McEwen and Leiman (2008) point out, the car guarding industry is (in an economic sense) a quasipublic good displaying the characteristics of being non-excludable, non-divisible and non-rival. This means that no customer can really be excluded from using the service, the allocation of car guarding cannot be split into usable units of time per car, and one additional customer does not preclude another customer from using the car guard service at the same time. Car guarding is therefore fundamentally different from restaurant service as the service acts more as a public good as opposed to a private good. That the effects of service quality on tipping extend even to this quasi-public service suggests that 
the desire to reward good service does not depend on a sense of focused personal obligation. Also consistent with this idea are the findings that customers who have a favorable impression of car guards and their social function were more likely to tip ( $\beta=$ .43 , Wald $(1)=4.85, \mathrm{p}<.03)$ and left larger tips $(\beta=.19, \mathrm{t}(1,322)=3.70, \mathrm{p}<.001)$ than customers with less favorable attitudes toward car guards.

Third, attitude toward helping other people was unrelated to tip ( $\beta=.03$, Wald (1) $=.02$, n.s.) but was significantly positively related to tip size $(\beta=.12, \mathrm{t}(1,322)=2.17, \mathrm{p}$ $<.04)$. These findings suggest that altruistic motives underlie consumers' decisions about how much to tip but not their decisions about whether or not to tip in the first place. The decision to tip incurs both monetary and non-monetary costs (e.g., walking to, or waiting for, the car guard in the heat and/or rain), but only monetary costs affect the decision about how much to tip once the decision to tip has been made. Perhaps altruistic motives are strong enough to overcome the monetary but not the non-monetary costs of tipping. This is particularly plausible given the small sums of money involved in car guard tipping (i.e. the average car guard tip of R2.00 is roughly US\$0.25).

Fourth, social norms were significantly positively related to tip $(\beta=.38$, Wald (1) $=4.16, \mathrm{p}<.05)$, but not to tip size $(\beta=.05, \mathrm{t}(1,322)=1.06$, n.s. $)$. However, social norms did interact with the presence of others in the car to predict tip size $(\beta=.20, \mathrm{t}(1$, $320)=2.29, \mathrm{p}<.03)$, such that social norms were positively related to tip size when other customers were in the $\operatorname{car}(\beta=.12, \mathrm{t}(1,150)=1.87, \mathrm{p}<.07)$, but not when the driver was alone $(\beta=.02, \mathrm{t}(1,155)=.23$, n.s. $)$. These findings make sense if customers tip for social approval from bystanders, because whether or not you tip is visible to all bystanders while the amount you tip is likely to be visible only to those who are very close by. Thus, these results provide strong support for the idea that social approval motives underlie the tipping of car guards in South Africa.

Fifth, attitude toward tipping car guards was unrelated to either tip $(\beta=-.03$, Wald $(1)=.02$, n.s. $)$ or tip size $(\beta=.07, \mathrm{t}(1,322)=1.14$, n.s. $)$, which suggests that car guard tipping in South Africa is not motivated by the internalization of tipping norms. This null finding is understandable by itself. The social pressures to tip car guards combined with the small monetary costs of doing so mean that customers tip even if they do not like the idea. However, this explanation should apply equally well to the attitude toward car 
guards, which was positively related to tipping. That one attitude measure predicted tipping while the other did not is very puzzling. Generally, attitudes are more predictive of behavior the greater the correspondence between the attitude measure and the behavior (Ajzen and Fishbein, 1977). In this case, that principle was violated because attitude toward car guards was more predictive of tipping behavior than attitude toward tipping car guards. Unfortunately, we could come up with no convincing explanation for this anomaly, so we leave it for future researchers to explain.

Finally, none of the demographic variables and only a few of the situational variables predicted tip or tip size. Not surprisingly, customers were less likely to leave a tip when they had no change $(\beta=6.05$, Wald $(1)=33.29, \mathrm{p}<.001)$ and when it was raining $(\beta=-.85$, Wald $(1)=5.55, \mathrm{p}<.02$ ). Also, customers left smaller tips on weekdays than on weekends $(\beta=.15, \mathrm{t}(1,322)=2.12, \mathrm{p}<.04)$ and at a shopping centers than at other locations $(\beta=-.16, \mathrm{t}(1,322)=-2.03, \mathrm{p}<.05)$. None of these effects are very interesting from a theoretical perspective, so they will not be discussed further.

\section{Conclusions}

From the perspective of mainstream economic theory, tipping is an anomalous, seemingly irrational behavior, because it is an expense that consumers are free to avoid (Lynn, 2006). Failure to tip does not result in any reduction in the goods or services that consumers receive, at least from infrequently patronized establishments. Thus, explanations for this economic behavior must go beyond the rational self-interest (i.e. homo economicus) idea that customers are motivated only by economic goods and services. Adequate explanations for tipping require a better approach that incorporates both rational motives (i.e. homo economicus) and psychological motives (i.e. homo psychologus), so recognizing potential motives such as the desires to reward good quality service, to help the service workers, to gain social approval/status, and to conform to internalized tipping norms. The current study empirically tests several of these motives, with the results supporting the idea that desires to reward good quality service, to help the service worker, and to gain social approval/status underlie the tipping of car guards in South Africa. Of course, additional motivations may underlie car guard tipping and the 
motives underlying tipping in this and other contexts and countries may differ, so more research on this topic is warranted. ${ }^{2}$ Hopefully, this paper will encourage more economists to look beyond the apparent irrationality of tipping and to study it from both a behavioral economics and psychological perspective.

\section{Acknowledgements}

The authors would like to thank Danie Petzer at the University of Johannesburg for assisting with the data collection.

\footnotetext{
${ }^{2}$ See Lee, Amir and Ariely's (2009) recent study on the role of emotions in consumer decision-making.
} 


\section{References}

Adams, S. (1965). Inequality in social exchange. In L. Berkowitz (Ed), Advances in Experimental Social Psychology, Vol. 2, New York: Academic Press.

Ajzen, I. and Fishbein, M. (1977). Attitude-behavior relations: A theoretical analysis and review of empirical research. Psychological Bulletin, 84, 888-918.

Azar, O.H. (2004). What sustains social norms and how they evolve? The case of tipping. Journal of Economic Behavior and Organiation, 54, 49-64.

Azar, O.H. (2005). Who do we tip and why? An empirical investigation. Applied Economics, 37(16), 1871-1879.

Azar, O.H. (2007a). Why pay extra? Tipping and the importance of social norms and feelings in economic theory. Journal of Socio-Economics, 36, 250-265.

Azar, O.H. (2007b). The social norm of tipping: A review. Journal of Applied Social Psychology, 37, 380-402.

Azar, O.H. (2008). Do people tip because of psychological or strategic motivations? An empirical analysis of restaurant tipping. Applied Economics, May, 1-6, iFirst.

Azar, O.H. (2009). Incentives and service quality in the restaurant industry: The tippingservice puzzle. Applied Economics, 41(15), 1917-1927.

Azar, O.H. (forthcoming). Tipping motivations and behavior in the U.S. and Israel. Journal of Applied Social Psychology, xx, xx-xx.

Barkan, R. \& A. Israeli, (2004). Servers' roles as experts and managers of tipping. The Service Industries Journal, 24(6), 91-108.

Bernstein, J. (2003). Car watch: Clocking informal parking attendants in Cape Town. Centre for Social Science Research Working Paper Number 55. Cape Town: CSSR, University of Cape Town.

Blaauw, P.F. \& Bothma, L.J. (2003). Informal labour markets as a solution for unemployment in South Africa: A case study of car guards in Bloemfontein. South African Journal of Human Resource Management, 1(2), 40-44.

Bodvarsson, O.B. \& Gibson, W.A. (1997). Economics and restaurant gratuities: Determining tip rates. American Journal of Economics and Sociology, 56, 187-203. 
Bodvarsson, O.B. \& Gibson, W.A. (1999). An Economic approach to tips and service quality: Results of a survey. The Social Science Journal, 36(1), 137-147.

Bodvarsson, O.B., Luksetich, W.A. \& McDermott, S. (2003). Why do diners tip: Rule-ofthumb or valuation of service? Applied Economics, 35(1), 1659-1665.

Conlin, M., Lynn, M. \& O'Donoghue, T. (2003). The norm of restaurant tipping. Journal of Economic Behavior and Organization, 52, 297-321.

Frank, R.H. (1988). Passions within reason. New York: W.W. Norton.

Frank, R.H. (2006). Microeconomics and behaviour. (6 $6^{\text {th }}$ ed.). Boston: McGraw-Hill Irwin.

Lee, L., Amir, O. \& Ariely, D. (2009). In search of homo economicus: Cognitive noise and the role of emotion in preference consistency. Journal of Consumer Research, 36(August), 173-187.

Lynn, M. (2004). Black-White differences in tipping of various service providers. Journal of Applied Social Psychology, 34(11), 2261-2271.

Lynn, M. (2006). Tipping in restaurants and around the globe: An interdisciplinary review. In: Atman, M. (Ed.), Handbook of Contemporary Behavioral Economics: Foundations and Developments. New York: M.E. Sharpe, (Chapter 31 pp. 626-643).

Lynn, M. (2008). Personality effects on tipping attitudes, self-reported behaviors and customs: A multi-level inquiry. Personality and Individual Differences, 44, 989-999.

Lynn, M. (2009). Individual differences in self-attributed motives for tipping: Antecedents, consequences and implications. International Journal of Hospitality Management, 28, 432-438.

Lynn, M. \& Grassman, A. (1990). Restaurant tipping: An examination of three 'rational' explanations. Journal of Economic Psychology, 11(1990), 169-181.

Lynn, M. \& McCall, M. (2000). Gratitude and gratuity: A meta-analysis of research on the service-tipping relationship. Journal of Socio-Economics, 29, 203-214.

Lynn, M., Sturman, M., Ganley, C., Adams, E., Douglas, M. and McNeil, J. (2008). Consumer racial discrimination in tipping: A replication and extension. Journal of Applied Social Psychology, 38(4), 1045-1060.

Lynn, M., Zinkhan, G.M. and Harris, J. (1993). Consumer Tipping: A Cross-Country Study. Journal of Consumer Research, 20(December), 478-488. 
McEwen, H. \& Leiman, A. (2008). The car guards of Cape Town: A public good analysis. Southern Africa Labour and Development Research Unit, Working Paper Number 25, Cape Town: SALDRU, University of Cape Town.

Payscale (2009). How's your tipping etiquette? Check out PayScale's tipping chart. Available at: http://www.payscale.com/tipping-chart (accessed Aug. 18, 2009).

Regan, D.T. (1971). Effects of a favor and liking on compliance. Journal of Experimental Social Psychology, 7, 627-639.

Schotter, A. (1979). The economics of tipping and gratuities: An essay in institution micro-economics. C.V. Star Center Working Paper Number 79-19, New York: New York University.

Schwer, R. K. \& Daneshvary, R. (2000). Tipping participation and expenditures in beauty salons. Applied Economics, 32(15), 2023-2031.

Star, N. (1988). The international guide to tipping. New York: Berkley Books.

Walster, E., Berscheid, E. \& Walster, G.W. (1973). New directions in equity research. Journal of Personality and Social Psychology, 25, 151-176.

Webb, D.J., Green, C.L. and Brashear, T.G. (2000). Development and validation of scales to measure attitudes influencing monetary donations to charitable organizations. Journal of the Academy of Marketing Science, 28(2), 299-309. 
Table 1. Descriptive statistics for the study variables.

\begin{tabular}{|c|c|c|c|c|c|}
\hline Variable & $\mathrm{N}$ & Minimum & Maximum & Mean & S.D. \\
\hline Tip & 530 & 0 (no) & 1 (yes) & 0.70 & 0.46 \\
\hline Tip Size & 372 & R0.50 & R20.00 & 3.94 & 3.15 \\
\hline Service Quality & 529 & $\begin{array}{l}1 \text { (strongly } \\
\text { disagree) }\end{array}$ & $\begin{array}{l}5 \text { (strongly } \\
\text { agree) }\end{array}$ & 3.44 & 0.78 \\
\hline Helping Motives & 530 & $\begin{array}{l}1 \text { (strongly } \\
\text { disagree) }\end{array}$ & $\begin{array}{l}5 \text { (strongly } \\
\text { agree) }\end{array}$ & 4.01 & 0.70 \\
\hline Attitude to Tipping & 530 & $\begin{array}{l}1 \text { (strongly } \\
\text { disagree) }\end{array}$ & $\begin{array}{l}5 \text { (strongly } \\
\text { agree) }\end{array}$ & 3.02 & 0.53 \\
\hline Attitude toward Car Guards & 530 & $\begin{array}{l}1 \text { (strongly } \\
\text { disagree) }\end{array}$ & $\begin{array}{l}5 \text { (strongly } \\
\text { agree) }\end{array}$ & 3.30 & 0.86 \\
\hline Social Norm & 530 & 1(definitely not tip) & 5 (definitely tip) & 3.57 & 0.80 \\
\hline Age & 528 & 1 (teens) & 7 (70’s) & 2.91 & 1.17 \\
\hline Sex & 528 & 1 (male) & 2 (female) & 1.45 & 0.50 \\
\hline Income & 514 & 1 (lower) & 5 (upper) & 3.04 & 0.94 \\
\hline Racial Status & 512 & 1(Black) & 3 (White) & 2.25 & 0.84 \\
\hline Car Guard Racial Status & 530 & 1 (Black) & 3 (White) & 1.23 & 0.57 \\
\hline $\begin{array}{c}\text { Car Guard National Origin: } \\
\text { South African }\end{array}$ & 530 & 0 (no) & 1 (yes) & 0.52 & 0.50 \\
\hline $\begin{array}{c}\text { Car Guard National Origin: } \\
\text { Foreign }\end{array}$ & 530 & 0 (no) & 1 (yes) & 0.21 & 0.41 \\
\hline Shopping Center & 530 & 0 (no) & 1 (yes) & 0.66 & 0.47 \\
\hline Weekend & 529 & 0 (weekday) & 1 (weekend) & 0.44 & 0.50 \\
\hline Night & 528 & 0 (day) & 1 (night) & 0.17 & 0.38 \\
\hline Frequency & 526 & 1 (never) & 4 (very often) & 2.98 & 0.85 \\
\hline Rain & 524 & 0 (no) & 1 (yes) & 0.17 & 0.38 \\
\hline Others in Car & 528 & 0 (no) & 1 (yes) & 0.50 & 0.50 \\
\hline Cash on You & 524 & 0 (no) & 1 (yes) & 0.87 & 0.34 \\
\hline
\end{tabular}


Table 2. Regression analyses predicting the decision to tip or not and tip size.

\begin{tabular}{|c|c|c|c|c|}
\hline \multirow[t]{2}{*}{ Dependent Variable } & \multicolumn{2}{|c|}{$\begin{array}{l}\text { Tip }(\text { yes }=1, \text { no }=0) \\
(\mathrm{n}=491)\end{array}$} & \multicolumn{2}{|c|}{$\begin{array}{l}\text { Tip Size (natural log transform) } \\
\qquad(\mathrm{n}=342)\end{array}$} \\
\hline & Main Effects Model & $\begin{array}{l}\text { Interaction } \\
\text { Effects Model }\end{array}$ & $\begin{array}{l}\text { Main Effects } \\
\text { Model }\end{array}$ & $\begin{array}{l}\text { Interaction Effects } \\
\text { Model }\end{array}$ \\
\hline Service Quality & $\begin{array}{l}.73^{* * *} \\
(11.50)\end{array}$ & $\begin{array}{l}\mathbf{1 . 6 9 * *} \\
(6.21)\end{array}$ & $\begin{array}{l}.14^{*} \\
(2.22)\end{array}$ & $\begin{array}{l}.37 \\
(1.89)\end{array}$ \\
\hline Helping Motives & $\begin{array}{l}.03 \\
(.02)\end{array}$ & $\begin{array}{l}.07 \\
(.10)\end{array}$ & $\begin{array}{l}.12 * \\
(2.17)\end{array}$ & $\begin{array}{l}.13 * * \\
(2.32)\end{array}$ \\
\hline Attitude to Tipping & $\begin{array}{l}-.03 \\
(.02)\end{array}$ & $\begin{array}{l}-.00 \\
(.00)\end{array}$ & $\begin{array}{l}.07 \\
(1.14)\end{array}$ & $\begin{array}{l}.09 \\
(1.38)\end{array}$ \\
\hline $\begin{array}{l}\text { Attitude toward Car } \\
\text { Guards }\end{array}$ & $\begin{array}{l}.43^{*} \\
(4.85)\end{array}$ & $\begin{array}{l}.44^{*} \\
(4.95)\end{array}$ & $\begin{array}{l}.19 * * * \\
(3.70) \\
\end{array}$ & $\begin{array}{l}.20 * * * \\
(3.94) \\
\end{array}$ \\
\hline Social Norm & $\begin{array}{l}.38^{*} \\
(4.16)\end{array}$ & $\begin{array}{l}.37 \\
(1.59)\end{array}$ & $\begin{array}{l}.05 \\
(1.06)\end{array}$ & $\begin{array}{l}-.06 \\
(-.89)\end{array}$ \\
\hline Age & $\begin{array}{l}-.06 \\
(.23)\end{array}$ & $\begin{array}{l}-.04 \\
(.09)\end{array}$ & $\begin{array}{l}-.01 \\
(-.22)\end{array}$ & $\begin{array}{l}-.01 \\
(-.22)\end{array}$ \\
\hline Sex & $\begin{array}{l}.28 \\
(.96)\end{array}$ & $\begin{array}{l}.29 \\
(1.07)\end{array}$ & $\begin{array}{l}-.10 \\
(-1.43) \\
\end{array}$ & $\begin{array}{l}-.08 \\
(-1.18) \\
\end{array}$ \\
\hline Income & $\begin{array}{l}.21 \\
(1.65)\end{array}$ & $\begin{array}{l}.19 \\
(1.36)\end{array}$ & $\begin{array}{l}.05 \\
(1.36)\end{array}$ & $\begin{array}{l}.05 \\
(1.38)\end{array}$ \\
\hline Racial Status & $\begin{array}{l}.01 \\
(.01) \\
\end{array}$ & $\begin{array}{l}.02 \\
(.02) \\
\end{array}$ & $\begin{array}{l}.01 \\
(.32) \\
\end{array}$ & $\begin{array}{l}.01 \\
(.15) \\
\end{array}$ \\
\hline Car Guard Racial Status & $\begin{array}{l}.25 \\
(.89)\end{array}$ & $\begin{array}{l}.31 \\
(1.11)\end{array}$ & $\begin{array}{l}.09 \\
(1.39)\end{array}$ & $\begin{array}{l}.07 \\
(1.17)\end{array}$ \\
\hline $\begin{array}{l}\text { Car Guard National } \\
\text { Origin: South African }\end{array}$ & $\begin{array}{l}.09 \\
(.08)\end{array}$ & $\begin{array}{l}.08 \\
(.06)\end{array}$ & $\begin{array}{l}.10 \\
(-1.21) \\
\end{array}$ & $\begin{array}{l}-.10 \\
(-1.23) \\
\end{array}$ \\
\hline $\begin{array}{l}\text { Car Guard National } \\
\text { Origin: Foreign }\end{array}$ & $\begin{array}{l}-.33 \\
(.70) \\
\end{array}$ & $\begin{array}{l}-.38 \\
(.91) \\
\end{array}$ & $\begin{array}{l}-.16 \\
(-1.56) \\
\end{array}$ & $\begin{array}{l}-.17 \\
(-1.73) \\
\end{array}$ \\
\hline Shopping Center & $\begin{array}{l}-.11 \\
(.14)\end{array}$ & $\begin{array}{l}-.16 \\
(.26)\end{array}$ & $\begin{array}{l}-.16 * \\
(-2.03)\end{array}$ & $\begin{array}{l}-.16 * \\
(-2.10)\end{array}$ \\
\hline Weekend & $\begin{array}{l}.16 \\
(.32) \\
\end{array}$ & $\begin{array}{l}.17 \\
(.36) \\
\end{array}$ & $\begin{array}{l}.15^{*} \\
(2.12)\end{array}$ & $\begin{array}{l}.15^{*} \\
(2.22)\end{array}$ \\
\hline Night & $\begin{array}{l}.44 \\
(1.22)\end{array}$ & $\begin{array}{l}. .43 \\
(1.11)\end{array}$ & $\begin{array}{l}-.09 \\
(-.93)\end{array}$ & $\begin{array}{l}-.09 \\
(-.90)\end{array}$ \\
\hline Frequency & $\begin{array}{l}.12 \\
(.48)\end{array}$ & $\begin{array}{l}1.15 \\
(2.68)\end{array}$ & $\begin{array}{l}.07 \\
(1.58)\end{array}$ & $\begin{array}{l}.33 \\
(1.51)\end{array}$ \\
\hline Rain & $\begin{array}{l}-.85^{*} \\
(5.55)\end{array}$ & $\begin{array}{l}-.80 * \\
(4.75)\end{array}$ & $\begin{array}{l}.05 \\
(.50)\end{array}$ & $\begin{array}{l}.05 \\
(.47)\end{array}$ \\
\hline Others & $\begin{array}{l}-.16 \\
(.30)\end{array}$ & $\begin{array}{l}-.29 \\
(.05)\end{array}$ & $\begin{array}{l}.11 \\
(1.46)\end{array}$ & $\begin{array}{l}.64 * \\
(-1.91) \\
\end{array}$ \\
\hline Cash & $\begin{array}{l}\text { 6.05*** } \\
(33.29) \\
\end{array}$ & $\begin{array}{l}\text { 6.12*** } \\
(33.40) \\
\end{array}$ & $\begin{array}{l}.33 \\
(.52) \\
\end{array}$ & $\begin{array}{l}.29 \\
(.46) \\
\end{array}$ \\
\hline SQ X Freq & & $\begin{array}{l}-.33 \\
(2.31) \\
\end{array}$ & & $\begin{array}{l}-.07 \\
(-1.20) \\
\end{array}$ \\
\hline SN X Others & & $\begin{array}{l}.04 \\
(.01)\end{array}$ & & $\begin{array}{l}.20 * \\
(2.29)\end{array}$ \\
\hline
\end{tabular}

Note: The table presents the regression coefficients, with Wald statistics or T-values in parentheses. $* \mathrm{p}<.05, * * \mathrm{p}<.01 * * * \mathrm{p}<.005$ (all p's two-tailed) 